\title{
Paulus se vernuftige vervlegting van antropologie en eskatologie in 2 Korintiërs 4:7-5:10
}

J A du Rand

(RAU)

\section{ABSTRACT}

Paul's ingenious intertwining of anthropology and eschatology in 2 Corinthians 4:7-5:10

It has been said that Paul is not really Pauline in his eschatological thoughts in 2 Corinthians 4:7-5:10. What could be the reason for that? The discourse is very personal. What emerges in the foreground are Paul's tribulations and suffering in his apostolic ministry. It is narrated in such a way that it forms the basis for understanding his anthropology and eschatology. His apostolic existence runs between two poles: his faith in Christ and his eschatological hope. Therefore, his anthropology is only to be understood in the light of his eschatology and his eschatology in the light of his anthropology.

\section{MOTIVERING EN AFBAKENING}

Die Franse eksegeet E B Allo het alreeds in 1937 gesê dat geen ander gedeelte in die Pauliniese corpus só misverstaan word as juis 2 Korintiërs 5:1-10 nie 1 . Dit word in 1973 onderskryf deur F G Lang wat honderd en vyftig jaar se kommentare oor die gedeelte nagegaan het ${ }^{2}$. Hy kom tot die gevolgtrekking dat dit die kommentatore self is wat wou verbeter op Paulus deur ' $n$ bepaalde Pauliniese eskatologie in te lees in dié paar verse. Die vraag is of Paulus volgens 2 Korintiërs 5:1-10 spesifieke dogmatiese eskatologiese uitsprake maak om sogenaamd in te pas by sy ander bekende eskatologiese getuienis, soos byvoorbeeld in 1 Korintiërs 15 of 1 Tess 4 .

Die uitgangspunt ten opsigte van afbakening in hierdie studie is dat 2 Korintiërs 5:1-10 logieserwys volg op 2 Korintiërs 4:7-18 en dat Paulus se ontberinge as apostel sy eskatologiese beredenering beïnvloed. Anders gestel, sy antropologiese uitsprake, veral vervat in 2 Korintiërs 4:7-18, hou verband met sy eie ontberinge as apostel en is medebepalend wat sy daaropvolgende eskatologiese opmerkings in 2 Korintiërs 5:1-10 betref. Paulus is dus nie on-Paulus nie, by wyse van spreke, maar voeg 'n nuwe dimensie toe aan sy bepeinsing oor die eskatologiese waarhede. Die volgende tersaaklike verkenning van sy inhoudelike argumentasielyn in 2 Korintiërs bevestig dit. 
Nadat Paulus sy verhouding met die gemeente verduidelik het, dink hy na oor die aard van sy bediening in 2 Korintiërs 2:14-7:16. Deur sy apostelbediening neem hy deel aan die triomftog van die evangelie deur die wêreld. Daarvoor dank hy God want die bekwaamheid kom van God alleen. Net soos Moses dienaar van die ou verbond van die wet was, só is Paulus dienaar van die nuwe verbond van die Gees. Die heerlikheid van die bediening van die wet is tydelik, maar die heerlikheid van die bediening van die Gees bring 'n nuwe bedeling tot stand. In dié nuwe bedeling is dit die Gees wat bevryding bring (2 Kor 3:7-19). Ten spyte daarvan dat die toekomstige nog voorlê, kan die gelowiges as bevryde mense (want die sluier is weggeneem) nou reeds die heerlikheid van die Here raaksien en word die beeld van Christus al meer in hulle sigbaar om daagliks meer en meer van die heerlikheid van Christus te vertoon. Deur die Gees raak hede en toekoms antropologies vervleg. Dit is die bediening van die Gees wat volgens Paulus die betekenisvolle ineenstrengeling van antropologie en eskatologie bewerkstellig.

Volgens 2 Korintiërs 4:7-15 is die bediening van die Gees, naamlik die proklamering van die kennis van die heerlikheid van God, 'n kosbare skat. Die bedienaar is egter breekbaar soos 'n tipiese "kleipot". Met meesterlike poësie verduidelik Paulus dat allerlei gevare dreig om die "kleipot" te vernietig maar dat dit tog deur God se ingrype behoue bly. Die verbondenheid aan Christus is die oorsaak van die verkondiger se alledaagse verdrukking en ontbering. Op só 'n wyse word Christus se lyding sigbaar in die lewe van die egte verkondiger. Die "kleipot" is oppad na sy liggaamlike dood. Ten spyte van daaglikse ontbering en risiko's bly die skat daarin ongeskonde en is die "kleipot" se toekoms ook geborg. Op grond van die verbondenheid aan Christus ly die gelowiges in die hede, maar is hulle ook verseker van hul uiteindelike bestemming. Só 'n eskatologiese perspektief bepaal ongetwyfeld ook Paulus se antropologiese opvattinge. Daarom is 2 Korintiërs 4:7-18'n noodsaaklike inleiding tot en deel van die verstaan van 2 Korintiërs 5:1-10.

Paulus gaan in 2 Korintiërs 4:16-5:10 voort met dieselfde argumentasielyn dat die uitsig op die toekomstige heerlikheid die verkondiger se hede vul met volharding en moed. Al beweeg Paulus ook uiterlik as gevolg van neerdrukkende omstandighede elke oomblik nader aan sy liggaamlike dood, word sy innerlike geestelike bestaan alreeds vernuwe deur die Gees, om deel te wees van die nuwe lewe wat in Jesus Christus aangebreek het. Die toekomstige heerlikheid moet nie as loon beskou word nie, maar as 'n alreedse motiverende perspektief waarvolgens die alledaagse betekenisvol en leefbaar word. Sy eskatologiese perspektief beïnvloed Paulus se antro- 
pologiese sieninge. Die gelowiges is tans in transito, maar wat rigting betref, oppad na die "vaste gebou" in die hemel. Die aardse tentwoning is tydelik maar noodsaaklik. Dit dwing die gelowige om eerder sy/haar perspektief te fokus op die onsigbare wat ewig is en nie op die sigbare nie. Die gelowige leef met 'n sug van ongeduld oor die knellende hede maar ook met 'n sug van verlange na die ewige. Ten spyte daarvan dat die tydelike met die ewige oorklee word, word die gelowige by wyse van beeldspraak ook bietjie vir bietjie ontklee. Die leef op aarde is daarom alleenlik moontlik omdat dit 'n leef deur geloof is. 'n Lewe tussen geloof en hoop. Die vervlegting van antropologie en eskatologie is treffend geillustreer in Paulus se eie eksistensiële bedieningsbestaan en toegepas op alle gelowiges. Dit is die tema wat 2 Korintiërs 4:7-5:10 saambind tot 'n eenheid.

\section{2 'N SELEKSIE UITLEGMOONTLIKHEDE}

Die belangrike eksegetiese werk deur N Baumert in 1973 word graag vermeld ${ }^{3}$. Hy het die mistieke karakter van 2 Korintiërs 4:12-5:10 beklemtoon deur die tradisionele eskatologiese interpretasie daarvan te vervang met 'n uitleg wat die gerealiseerde of teenswoordige interpretasie genoem kan word. Die grammaties futuristiese $\dot{\varepsilon} \gamma \varepsilon \rho \varepsilon \hat{\imath}$ ("sal opwek") en $\pi \alpha \rho \alpha \sigma \tau \tilde{\eta} \sigma \varepsilon \iota$ ("sal stel") in 2 Korintiërs 4:14 verduidelik hy byvoorbeeld as modale toekomstige tyd met die betekenis: God moet ons opwek en ons voor sy troon stel. En dit geskied nie eers by die finale opstanding nie, maar reeds in die hede. Dit klink oorspronklik maar is geforseerd en laat nie reg geskied aan die betekenis van dié gedeelte nie. Om die opstanding van die gelowige te beperk tot 'n mistieke gebeure, ontdaan dié gedeelte van sy futuristiese eskatologiese bedoeling.

Só gaan Baumert voort om byvoorbeeld 2 Korintiërs 4:16-18, waar Paulus praat van die uiterlike en innerlike, as 'n soteriologiese dualisme te beskryf, eerder as ' $n$ antropologiese dualisme tussen liggaam en gees ${ }^{4}$. Net só verwys die bekleding van die aardse woning deur die hemelse in 2 Korintiërs 5:2 na die alreeds historiese tydvak en nie na die lewe hierna nie $^{5}$. Daarom moet B $\alpha \rho o u ́ \mu \varepsilon \nu o \iota$ ("neergedruk te word") in 2 Korintiërs 5:4 nie in Platonies-antropologiese sin verstaan word nie, maar bloot as die las van die apostoliese bediening6. Alhoewel Baumert konsekwent die alreedse beklemtoon en nie net die futuristiese nie is sy interpretasies vergesog en onbewese. Hy het te hard probeer om die verwysings na die toekomstige te "ontfuturiseer".

Nog 'n moontlike verklaring van dié gedeelte wat aanhang geniet, is die Christologiese interpretasie. Die bekendste voorstander is J A T 
Robinson wat byvoorbeeld die hemelse tuiste volgens 2 Korintiërs $5: 1 \mathrm{~b}$ Christologies uitlê. Dit is 'n korporatiewe tuiste in Christus ${ }^{7}$. Saam met Robinson meen Collange 8 dat Paulus sy idee van 'n "hemelse tuiste" gevind het by die logion volgens Markus 14:58 waar Jesus sê: "Ek sal hierdie tempel wat deur mense gemaak is, vernietig en binne drie dae 'n ander een bou wat nie deur mense gemaak is nie". Dit sou bloot "biblizistisches Kombinatzionsverfahren", volgens Lang9, genoem kon word want Paulus gebruik nie eers die woord $\nu \alpha o ́ s$ (tempel) nie en woorde soos

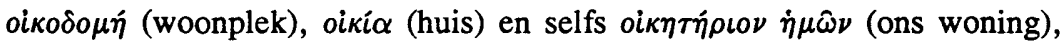
volgens vers 2 , het nie as sodanig Christologiese verbintenisse nie.

Op voetspoor van Bultmann ${ }^{10}$ het veral Schmithals ${ }^{11}$ en Hoffmann ${ }^{12}$ ernstige pogings aangewend om te bewys dat Paulus in 2 Korintiërs 4-5 polemiese bedoelinge het teen die gnostiserende opponente in Korinte. Die verwysings byvoorbeeld na 'n moontlike tussenstaat in 2 Korintiërs 5:3 en 8 moet teruggevoer word na die terminologie van die gnostiserende opponente. Só 'n interpretasie is vergesog en geforseerd. 'n Mens sou wel moet

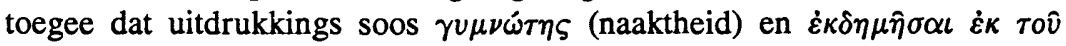
$\sigma \omega \dot{\omega} \mu \alpha \tau \varsigma$ (om afwesig te wees uit die liggaam) in 2 Korintiërs 5:3 en voorkom in Paulus se argumentasie teen die tipiese Grieks-gnostiese teorie van 'n suiwer geestelike (naakte) bestaan ná die dood. In só 'n geval sou verlossing ' $n$ bevryding van die liggaam kon beteken. Paulus sien die mens se gees en liggaam egter as 'n onskeibare eenheid.

$\mathrm{Al}$ die genoemde uitlegmoontlikhede, naamlik die futuristies eskatologiese, oorbeklemtoonde gerealiseerde, Christologiese of polemies teen gnostiese teenstanders laat as sodanig nie reg geskied aan die Pauliniese teks nie. Paulus het nie noodwendig uiterlike teenstanders in gedagte nie maar kon bloot verwys het na sy eie ontberinge en lyding ter wille van die evangelie. Lê die sleutel tot die verstaan van die eskatologiese nie in die antropologiese en ook andersom nie?

Paulus se persoonlike ervaringe as evangeliedienaar dra ongetwyfeld 'n groot deel by tot die formuleringe van sy antropologie en eskatologie. Veral die volgende uitdrukkings dra 'n persoonlike stempel en is van belang vir sy antropologie: die verhouding tussen die "skat" en die "kleipot" ( 2 Kor 4:7); dié tussen die "uiterlike" en innerlike mens (2 Kor 4:16); die beelde van die "huis" (2 Kor 5:1-2), kleding (2 Kor 5:2-4) en "verblyf in die liggaam wat verlaat word" (2 Kor 5:6-9). En verder: om "die sterwe van Jesus in ons liggaam saam te dra" (2 Kor 4:10); om "die lewe van 
Jesus in ons liggaam sigbaar te maak" (2 Kor 5:10); die "swaarkry in hierdie lewe" ( 2 Kor 4:17); ons "aardse woning wat maar 'n tent" is (2 Kor 5:1); die prominente adjektief "nakend" ( $\gamma v \mu \nu o i: 2$ Kor 5:3); ons verblyf in die liggaam (2 Kor 5:6,8) en die tussentydse lewe deur geloof deur nie te sien nie (2 Kor 5:7). Die dinge wat Paulus elke dag beleef, figureer op die voorgrond. 'n Mens dink veral aan sy fisiese aftakeling,

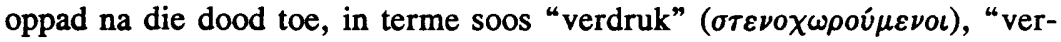

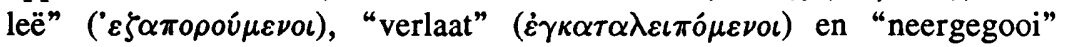

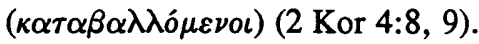

Om die "sterwe" ( $\nu \varepsilon ́ \kappa \rho \omega \sigma \varsigma)$ van Jesus altyd in die liggaam saam te dra (2 Kor 4:10), vorm die samevattende tema van sy ontberinge. Dit gaan oor die realisering van "sterwe" ( $\nu \varepsilon ́ k \rho \omega \sigma \iota \varsigma)$ wat in verskeie vorms manifesteer. Dié "sterwe" ( ontvlug nie. Dit is altyd aanwesig as 'n herinnering daaraan dat ons uitgelewer is aan die dood ter wille van Jesus (2 Kor 4:11). Die voortgaande sterwe ( $\nu \varepsilon \hat{\varepsilon} \kappa \rho \omega \sigma \iota \varsigma)$ is ter wille van Jesus ( $\delta \iota \grave{\alpha}$ 'I $\eta \sigma o \hat{v} \nu)$ !

Ten spyte van die "uiterlike vergaan" ( $\delta \iota \alpha \phi \theta \varepsilon i \rho \tau \alpha \iota)$ volgens 2 Korintiërs 4:16, die "swaarkry" ( $\theta \lambda \hat{\imath} \psi \iota \varsigma)$ in die daaropvolgende vers 17 en die "afbreek" ( $\kappa \alpha \tau \alpha \lambda \nu \theta \hat{\eta})$ van ons aardse woning in 2 Korintiërs $5: 1$, word die gelowige innerlik vernuwe met 'n uitsig wat aan die daaglikse lewe insig bied.

Die vlugtige flitse wat 'n mens van die mens Paulus se lewensloop kry, volgens die Nuwe Testament, bevestig dat hy heelwat ontberinge moes verduur. Daar is sprake van probleme op reise, die las van handearbeid (vgl Hand 18:3; 20:34) en siektes wat hom oorval het (2 Kor 12:7; Gal 4:13). In die provinsie Asië het hy selfs die hoop om te bly lewe laat vaar (2 Kor 1:8,9). Dit verwys moontlik na sy vervolgings, hongerly, gevangeskappe, slaaplose nagte en slae (2 Kor 6:4-5; 11:23v).

Hoe hanteer die apostel-evangeliedienaar sulke teenslae? Met gelatenheid, volgens 2 Korintiërs 12:10, as Paulus sê: "Daarom is ek bly ( $\varepsilon \dot{v} \delta \circ \kappa \hat{\omega})$ oor swakhede, beledigings, ontberings, vervolging en moeilikhede ter wille van Christus, want as ek swak is, is ek sterk". Die $\varepsilon \dot{v} \delta o \kappa \hat{\omega}$ moet nie psigologies of selfs masochisties verstaan word nie ${ }^{13}$. Paulus "aanvaar" met gelatenheid wat oor hom kom. Volgens 2 Korintiërs 4:7-

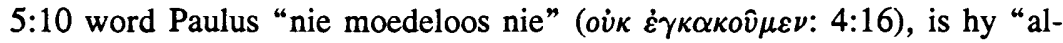
tyd vol moed" ( $\theta \alpha \rho \rho o \hat{\nu} \tau \varepsilon \varsigma: 5: 6$; cf 5:8) op grond van veral twee redes:

* Paulus "leef deur geloof” ( $\delta \iota \grave{\alpha} \pi i \sigma \tau \varepsilon \omega \varsigma \pi \varepsilon \rho \iota \pi \alpha \tau o \hat{v} \mu \varepsilon \nu$ )

* Hy koester 'n lewende eskatologiese "hoop" 
Daarby sou gevoeg kon word dat Paulus in die volgende paragraaf, 2 Korintiërs 5:14, sê dat "die liefde van Christus ons dwing". Die

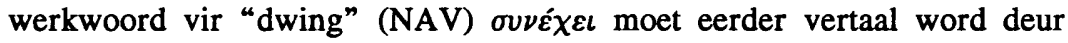
"bind", "beheer" en "vashou" in die sin van "hou ons in sy mag". Dit is die liefde van Christus wat ons beheer in God se hand ${ }^{14}$.

Om Paulus se ontberinge ook in die perspektief van die eskatologiese hoop te verstaan, open betekenisvolle perspektiewe. Hy trek byvoorbeeld 'n parallel tussen Christus se opstanding en dié van homself en die gelowiges (2 Kor 4:14). Sy bestemming is "'n heerlikheid wat alles verreweg oortref en wat ewig bly" ( 2 Kor 4:17) ${ }^{15}$. Die stelling in 2 Korintiërs 4:18 dat die sigbare dinge tydelik is maar die onsigbare ewig, moet nie in die sin van die metafisiese, soos in die Griekse literatuur ${ }^{16}$, verstaan word nie, maar eskatologies, as dit wat moet kom. Dit het 'n Joodse kleur gekry'17. Ook sy "sug" en "verlang" ( 2 Kor 5:2) in die praesensvorm van die werkwoord dui op die intense lewende begeerte en uitsien na dit wat kom. Dieselfde boodskap van sekerheid straal uit die paesens "ons weet... dat ons 'n woning, deur God gemaak, het... volgens 2 Korintiërs 5:1 (oi $\alpha \mu \varepsilon \nu$

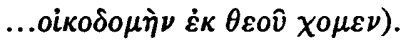

Die metafoor "om beklee te word" ( 2 Kor 5:2, 4) word ook in 1 Korintiërs 15:53-54 eskatologies toegepas wanneer Paulus sê dat "hierdie verganklike liggaam met die onverganklike beklee moet word en hierdie sterflike liggaam met die onsterflike". Dit verduidelik 2 Korintiërs 5:2 en 4. En wanneer die Gees verbind word aan $\dot{\alpha} \rho \rho \alpha \beta \hat{\omega} \nu$ in 2 Kor 5:5, vestig dit ons aandag op die "eerste vereffening" wat gedoen is met die verwagting van die volmaakte wat nog moet kom ${ }^{18}$. Die hele aardse lewe met al sy ontberinge stuur vir Paulus af op 'n bepaalde bestemming. Die rigting

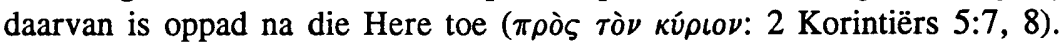
Die finale eindpunt word in hierdie geval die verskyning "voor die regterstoel van Christus" genoem in 2 Korintiërs 5:10.

Samevattend sou ons oor Paulus se persoonlike aardse reis kon sê dat dit begin by sy bekering waarop gesinspeel word in 2 Korintiërs 4:6 en eindig by die eskatologiese regterstoel van Christus ( 2 Kor 5:10) volgens die afgebakende gedeelte. Anders gestel, Paulus beweeg tussen 'n volhardende geloof en eskatologiese hoop in sy belewing van die huidige aardse reis.

\section{VANUIT 'N ANTROPOLOGIESE GESIGSHOEK}

In die gekose gedeelte is ten minste vyftien uitdrukkings ${ }^{19}$ en verwysings wat aangewend kan word in die formulering van die Pauliniese antropo- 
logie. Dié antropologie is ten nouste verbind aan die onderliggende apostoliese ontberings wat Paulus beleef, soos hierbo aangetoon. Paulus se

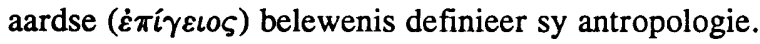

'n Belangrike hermeneutiese vraag wat dikwels al geopper is, is of die antropologie van 2 Korintiërs 4:7-5:10 Judaïsties, Grieks-Hellenisties of eksklusief Christelik is ${ }^{20}$. Sonder enige twyfel is die volgende eksklusief Christelik: die sterwe en opstaan met Christus (2 Kor 4:10-12); die opwekking van Christus (2 Kor 4:14) en die gawe van die Gees as $\alpha \rho \rho \alpha \beta \hat{\omega} \nu$ (2 Kor 5:5). Aan die ander kant, is 2 Korintiërs 4:16-18 sterk Judaïsties beïnvloed, tot só 'n mate dat Windisch daarvan gesê het dat dit net só deel kon gewees het van 'n Joodse apokalips of 'n brief van Seneka'1.

Vier antropologiese momente word as voorbeelde, by wyse van seleksie, kortliks van naderby toegelig: die skat in kleipotte ( 2 Kor 4:7); die uiterlike en innerlike mens ( 2 Kor 4:16); die metafoor van die huis ( 2 Kor 5:1-2) en die teenstelling geklee/naak (2 Kor 5:2-4).

Die eerste voorbeeld vind ons in 2 Korintiërs 4:7: "Ons wat hier-die skat in ons het, is maar kleipotte wat maklik breek...". Dit is die verlossende krag van God wat gekontrasteer word met die "breekbaarheid" van die apostel as instrument van God"2 . Die metafoor van 'n "houer", aangewend in antropologiese sin, is bekend in die Griekse Romeinse wêreld. Sisero praat van die liggaam as 'n houer van die gees ${ }^{23}$. Die presiese term $\sigma \kappa \varepsilon \hat{v} 0 \varsigma$ as "houer" of "kleipot" in antropologiese sin kom net in Bybelse tekste voor ${ }^{24}$. God is daarvolgens die pottebakker as Skepper ${ }^{25}$. Die metafoor "kleipot" word nie gekontrasteer met byvoorbeeld "gees" $\left(\psi v \chi \eta^{\prime}\right)$, soos in die buite-Bybelse Griekse literatuur nie, maar met die "skat" ( $\theta \eta \sigma \alpha u ́ \rho \circ)$. Die skat is nie die "gees" nie maar die "kennis van die heerlikheid van God" wat in ons harte ingeplant is (2 Kor 4:6). Dit hou

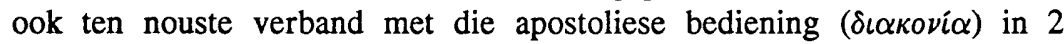
Korintiërs 4:1. Dit is die bediening van die nuwe verbond. Die brose, breekbare mens as draer van die "skat" moet dié boodskap van die evangelie verder dra. Paulus se gebruik van $\sigma \kappa \varepsilon v \hat{\jmath} \circ$ is vanuit antropologiese hoek gesien uniek. Dit betrek die mens se liggaamlikheid maar word nie dualisties gestel teenoor sy gees nie.

Die tweede voorbeeld fokus op 'n teenstelling tussen die uiterlike $(\dot{o}$ $\widehat{\varepsilon} \zeta \omega \dot{\eta} \mu \hat{\omega} \nu \not{\alpha} \nu \theta \rho \omega \pi \circ \varsigma$ ) en innerlike mens ( $\dot{o} \ddot{\varepsilon} \sigma \omega \dot{\eta} \mu \hat{\omega} \nu$ ). Dit is 'n tipiese voorbeeld uit die Griekse filosofiese invloedsfeer ${ }^{26}$. In dié voorkomste verwys die "uiterlike mens" na die menslike liggaam en die materiële sy van menswees. Dit is ook die betekenis waarin Paulus dié uitdrukking gebruik, maar met die vooruitsig van die opwekking (2 Kor 4:14). Daarom verskil hy tog van die omliggende tipiese Griekse denke. 
Wat die "innerlike mens" betref, verskil Paulus aansienlik van die Hellenistiese opvattinge. Volgens laasgenoemde beteken "innerlike mens" die "siel" of "gees" $(\psi v \chi \dot{\eta})$ of die "rede" ( $\nu$ ov $\varsigma)^{27}$. In die gnostiese denke is "innerlike mens" die "goddelike vonk". Volgens Griekse denke is "innerlike mens" vervat in 'n dualistiese denksisteem waarvolgens die mens se liggaam of uiterlike die "tronk" van die gees is, aldus Plato28. Volgens Paulus is die "innerlike mens" nie net 'n neutrale psigologiese saak nie. Dit word gedefinieer deur uitdrukkings soos "die lewe van Jesus" wat ons in ons omdra ( 2 Kor 4:10), "die Gees wat die geloof werk" ( 2 Kor 4:13) die "Gees" wat God gegee het (2 Kor 5:5), asook verderaan: "'n nuwe mens" of "nuwe skepping" (OAB) (2 Kor 5:17).

Die geestelike ingesteldheid is die innerlike gevolg van die gawe van die Gees. Dit is die Christus wat in die gelowige gestalte aanneem, by wyse van spreke. Net soos Galasiërs 2:20 dit stel: "nou is dit nie meer ek wat lewe nie, maar Christus wat in my lewe". Die nuwe "innerlike mens" kan ook in verband gebring word met Galasiërs 4:19 wat dit só treffend

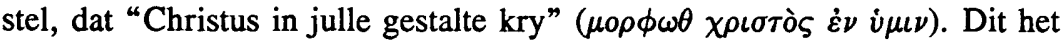
nog nie volkome gebeur nie, daarom die klem op die uitdrukking: "word ons van dag tot dag vernuwe" ( $\dot{\alpha} \nu \alpha \kappa \alpha \iota \nu 0 \hat{v} \tau \alpha \iota, 2$ Kor 4:16). Dit is 'n proses waarvolgens die Gees wat deur God aan ons geskenk is as waarborg die "nuwe skepping" ( 2 Kor 5:17) in ons werk sodat die "innerlike mens" al meer die gestalte van Christus vertoon. Die antropologiese dualisme, indien dit só genoem kan word, lê tussen die sterflike uiterlike liggaam en die innerlike gees wat vernuwe word deur die Goddelike Gees.

'n Derde antropologiese metafoor wat Paulus in dié gedeelte gebruik, is dié van 'n "huis". In 2 Korintiërs 5:1-2 gebruik hy die

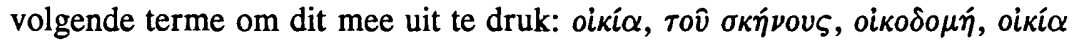

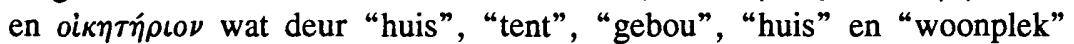
vertaal kan word. Net Plato, sover vasgestel kon word, praat van die dood as 'n "verandering van woonplek" ( $\mu \varepsilon \tau о i \kappa \eta \sigma \varsigma)^{29}$. Sisero noem die aardse lewe nie eers 'n woning nie, maar net 'n "gastehuis" (hospituum) ${ }^{30}$. Die ware woning is die hemel nadat iemand gesterf het ${ }^{31}$.

Die uitdrukking "tentwoning" (oiki $\alpha$ rô $\sigma \kappa \dot{\eta} \nu o v \varsigma$ ) in 2 Korintiërs 5:1 word dominant deur die begrip "tent" gespesifiseer ${ }^{32}$. Paulus beklemtoon dat ons aardse lewe soos 'n tentverblyf, wat net tydelik kan wees, afgebreek word. Hy dink in elk geval nie dualisties nie. Die toekomstige lewe raak die hele persoon en nie net iemand se gees $\left(\psi v \chi \eta^{\prime}\right)$ nie. Vervleg met die metafoor van die "huis" is dié van "verhuising" of die "uittog" (2 Kor 5:6-9). Die mens is oppad vanaf die aardse woning na die eintlike woning wat in die toekoms lê. Is dit nie kostelik nie as Sokrates ten opsigte van sy 
eie lewe praat van 'n "emigrasie" ( $\dot{\alpha} \pi o \delta \eta \mu i \alpha){ }^{33}$. Filo noem die hele lewe in die liggaam 'n "ballingskap" 34 .

Die Pauliniese uitdrukkings "om in die liggaam te bly" (2 Kor 5:6) en "om die verblyf in die liggaam te verlaat" (2 Kor 5:6) suggereer 'n dualistiese antropologie. Paulus stel dit egter nie teenoor die gees $\left(\psi v \chi \chi^{\prime}\right)$ nie. Hy praat ook nie veragtend van hierdie lewe nie, maar sinspeel bloot op sy teistering as apostel van Jesus Christus. Daarom verskil sy metaforiese verduideliking van die "verlaat van die verblyf in die liggaam" van die tipiese aanbieding van dieselfde saak volgens die Griekse denke. Hy leun eerder oor na die Semitiese en Christologiese misterie van die pasga en paasgebeure.

Die vierde geselekteerde voorbeeld het te make met die "klee" en "ontklee" as metafoor (2 Kor 5:2-4) ${ }^{35}$. Paulus praat twee keer daarvan om iets oor iets anders aan te trek $(\dot{\varepsilon} \pi \varepsilon \nu \delta \dot{v} \sigma \alpha \sigma \theta \alpha \iota)(2$ Kor 5:2 en 4). Dit beteken nie om iets uit te trek nie, maar om iets anders oor die bestaande aan te trek. Die ooreenkoms met die Grieks-Romeinse denkwêreld is ook in hierdie geval beperk tot terminologie. Paulus sien die "naaktheid of dood" nie as 'n fisiese tot niet gaan soos die Grieke nie. Hy stel ook nie die liggaamlike dood teenoor die geestelike nie maar kontrasteer eerder die antropologiese hede met die toekomstige bestemming.

\section{ENKELE ESKATOLOGIESE MOMENTE}

Volgens 'n eerste waarneming van die eskatologiese uitsprake in 2 Korintiërs 4:7-5:10, sou 'n mens kon sê dat dit geensins sistematies uiteengesit is nie. Dit verskil ook aansienlik van die tipiese Pauliniese eskatologie volgens 1 Korintiërs 15 en 1 Tessalonisense 4. Die woord parousiva kom ook nie in 2 Korintiërs 4:7-5:10 voor nie, alhoewel daarop gesinspeel word in 2 Korintiërs 5:3 en 10. Die begrip eskatologiese hoop word nietemin op 'n verfynde teologiese wyse vervleg met Christologiese geloof vanuit die eksistensiële ervaringswêreld van die teisteringe van Paulus in sy apostoliese bediening.

Die kragtigste eskatologiese uitsprake is onteenseglik die verwysing na die opwekking in 2 Korintiërs 4:14, asook die voorwaardelike sin in 2 Korintiërs 5:1, waar sprake is van 'n "vaste gebou in die hemel" nadat "die aardse tentwoning afgebreek" is. Die voorwaardelike protasis $\dot{\varepsilon} \dot{\alpha} \nu$... $\kappa \alpha \tau \alpha \lambda \nu \theta \hat{\eta}$ ("as ... afgebreek word") het die semiotiese funksie dat die klem

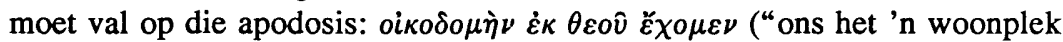
deur God gemaak"). Die sekerheid van die wete dat ons 'n woonplek by God het, domineer die hele voorwaardelike segging. Dit is ook bepalend in 
Paulus se eskatologiese uitsig. By so 'n uitsig vind hy insig wat sy daaglikse stryd en swaarkry betref. Sy gedagtegang verloop net soos in 'n tipiese Judaïstiese patroon a minori ad maius - van die geringe tot die grotere: van die teistering in die alledaagse aardse lewe tot die heerlikheid wat nog moet $\mathrm{kom}^{36}$. In dié opsig verskil 2 Korintiërs 4-5 se eskatologie van dié van 1 Korintiërs 15.

Die onderliggende bewustheid van Paulus se teistering in sy apostoliese bediening bied drakrag aan die eskatologiese uiteensetting in 2 Korintiërs 4-5 en ontbreek in 1 Korintiërs 15. In 1 Korintiërs 15 ontbreek die moment van die eskatologiese oordeel. Dit vorm die sluitsteen van hierdie gedeelte in 2 Korintiërs 4:14 en kan as tipies Judaïsties apokalipties beskou word. Daarvolgens ontvang die lydende party 'n finale beloning in die toekoms (Dan 7) ${ }^{37}$.

Die volgende geselekteerde eskatalogiese momente in 2 Korintiërs 4:7-5:10 word kortliks aangesny:

* Paulus is deurgaans diep bewus van sy dood. Nie net die finale afsluiting van sy fisiese bestaan nie, maar ook die daaglikse doding wat hy as gevolg van die teistering ondervind. Vergelyk byvoorbeeld die "afbreek" ( $\kappa \alpha \tau \alpha \lambda \nu \theta \hat{y})$ van die aardse tentwoning (2 Kor 5:1), asook om "uitgelewer te word $(\pi \alpha \rho \alpha \delta \iota \delta o ́ \mu \varepsilon \theta \alpha)$ aan die dood" (2 Kor 4:11) en "om uiterlik te vergaan" ( $\delta \iota \alpha \phi \theta \varepsilon \iota \rho \varepsilon \tau \alpha \iota)$ (2 Kor 4:16). Dit is nie dieselfde as Seneka se "ons sterf daagliks" nie ${ }^{38}$. Paulus fokus op die eskatologiese aspek en nie op die eksistensiële soos in die tipiese Griekse denke nie. Die dood wat ons sterf, vind plaas deurdat ons huidige historiese liggaam wat breekbaar is ( 2 Kor 4:7), vernuwe word en met die ewige oorklee word ( 2 Kor 5:2-4), om uiteindelik by die Here te gaan woon (2 Kor 5:6, 8).

Ná die dood voorsien Paulus 'n liggaamlike dimensie wat verskil van die aardse. Daarom praat hy nie van die "siel" of "gees" $\left(\psi v \chi \chi^{\prime}\right)$ ná die dood nie, maar van die hele mens wat as 'n nuwe $\sigma \omega \mu \alpha$ verstaan kan word (2 Kor 5:2). Net soos die Fariseërs (waarvan hy een was) glo Paulus dat die gees van die mens verhuis "na 'n ander liggaam" ( $\varepsilon i \varsigma$ $\dot{\varepsilon} \tau \varepsilon \rho \circ \nu \sigma \hat{\omega} \mu \alpha)^{39}$.

* Paulus se siening oor iemand se toestand ná die dood is ook tipies Judaïsties, naamlik dat 'n mens 'n nuwe liggaam aanneem. Die begrip "naaktheid" in 2 Korintiërs 5:3 sien moontlik op die ewige verdoemenis. Paulus wil nie "naak" of veroordeeld en skuldig voor God staan 
nie, maar geklee wees met Jesus Christus (2 Kor 5:3, 4). Collange beskou dié naaktheid as ' $n$ toestand van verwydering van Christus wat as die "kleed" voorgestel word ${ }^{40}$. Dit is egter nie 'n Pauliniese gedagte om tussen dood en opstanding as gelowige verwyderd van Christus te wees nie. Net soos in die Judaïsme (ongeveer $100 \mathrm{vC}$ tot $100 \mathrm{nC}$ ) gee Paulus ook nie 'n gesistematiseerde uiteensetting van die presiese toestand van die mens na sy dood nie ${ }^{41}$.

* Die eskatologiese rol wat die Gees speel, moet beklemtoon word (2 Kor 5:5). God bewerk die oorgang ( $\alpha \tau \varepsilon \rho \gamma \alpha \dot{\alpha} \zeta o \mu \alpha \iota)$ vanaf hierdie lewe na die lewe hierna. 2 Korintiërs 5:5 waar sprake is van die Gees $(\pi \nu \varepsilon \dot{v} \mu \alpha)$ wat as “waarborg” $(\dot{\alpha} \rho \rho \alpha \beta \hat{\omega} \nu)$ gegee is, moet ten nouste saam met die voorafgaande vers 4 gelees en verstaan word. Die

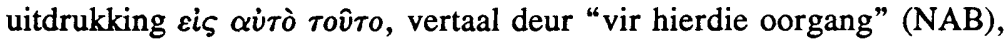
gryp terug na die voorafgaande fokus op die "aantrek van die hemelse bo-oor die aardse" (2 Kor 5:4). Die gawe van die Gees is bestem om die Christen se "oorgang" solank voor te berei. Daarom is die Gees $(\pi \nu \varepsilon u ́ \mu \alpha)$ nie maar net volgens Paulus 'n mistieke werklikheid nie, maar 'n eskatologiese dinamiese bewerker van God se toekoms vir die gelowige in die alreedse hede. Die "waarborg" $(\dot{\alpha} \rho \rho \alpha \beta \hat{\omega} \nu)$ is reeds teenwoordig, maar het die funksie om die Christen te herinner aan die volmaakte wat nog moet aanbreek. Dit is merkwaardig parallel aan Romeine 8:11 waar ons lees: “... sal Hy deur wie Christus uit die dood opgewek is, ook julle sterflike liggame lewend maak deur sy Gees wat in julle woon". In dié geval word die Gees se werk betrek op die opstanding van die gelowige en in 2 Korintiërs 5 op die eskatologiese "vernuwing" van die Christen ${ }^{42}$. Paulus beklemtoon die kousale verband tussen die Gees en die opstanding, maar ook tussen die Gees en die eskatologiese bestemming van die gelowige ${ }^{43}$. Wat nou reeds begin het deur die Gees moet sy volmaaktheid bereik in die gelowige se toekomstige bestemming. Dit is die gang van die "nuwe skepping"

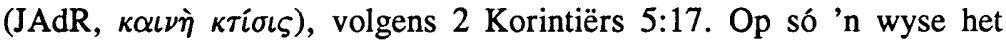
Christus se verdiende onsterflikheid deur die gawe van die Gees ons nietige mensheid binnegedring. Al sou die gelowige se liggaam ook tot sterwe kom, God het reeds in die mens deur sy Gees die uiteindelike bestemming "ingebou", by wyse van spreke.

\section{6 'N SLOTWOORD}

In 2 Korintiërs 4:7-5:10 as eenheid slaag Paulus daarin om op meesterlike wyse, geheel en al verskillend van sy Judaïstiese en Griekse agtergronde, 
die gelowige se aardse lewe en uiteinde in verband te bring met sy eie wedervaringe as apostoliese dienaar. Antropologie en eskatologie word vervleg met Paulus se persoonlike lydenspad as gegewe agtergrond vir die verstaan daarvan. Paulus slaag daarin om sy eie teenslae nie psigologies aan te wend nie, maar om dit toe te pas op die antropologie van elke gelowige wie se bestaan uitloop op 'n heerlikheid in 'n lewe hierna. Paulus se "eie verhaal" as korporatiewe voorbeeld begin by die breekbare "kleipot" ( 2 Kor 4:7), kom in fokus met die korporatiewe paasgebeure in 2 Korintiërs 4:10-12 en bereik 'n klimaks met die eskatologiese perspektief in 2 Korintiërs 4:17-18: die "swaarkry in hierdie lewe" loop uit op "'n heerlikheid wat alles oortref". Die "innerlike mens", gedefinieer deur die Gees, is ook eskatologies geborg deur die Gees. Paulus se antropologie is eskatologies georiënteer. Die "nuwe skepping" in die gelowige waaraan hy/sy deur die Gees as waarborg herinner word, kan nie sterf nie, omdat die aanvang van die volmaakte reeds teenwoordig is. Daarom, het die gelowige net "een wens en dit is om te lewe soos Hy dit wil" (2 Kor 5:9).

\section{NOTAS:}

1 E B Allo, Seconde Épitre aux Corinthiens, Paris 1937, 134, aangehaal deur R Penna, Paul the apostle. Jew and Greek alike, (translation $\mathrm{P}$ Wahl), Collegeville 1991, 232.

2 F G Lang, 2 Korinther 5:1-10 in der neueren Forschung, Tübingen 1973, 76.

3 Vergelyk N Baumert Täglich sterben und auferstehen. Der Literalsinn von 2 Kor 4, 12-5, 10, München 1973.

$4 \quad$ Kyk Baumert, $a w, 123$.

5 Baumert, $a w, 197$.

6 Baumert, $a w, 249$. Die hele behandeling van die metafoor "beklee" is volgens Baumert 'n verwysing na die "himmlisches" wat nou reeds in die gelowige se aardse liggaam aanwesig is.

7 J A T Robinson, The body: A study in Pauline theology, Philadelphia 1977, 7678.

$8 \quad$ M Collange, Enigmes de la Deuxième Épître aux Corinthiens. Etude exégetique de 2 Cor 2:14-7:4, Cambridge 1972, 171-174.

9 Vergelyk sy 2 Korinther 5, 1-10, 185.

10 R Bultmann, Exegetische Probleme des zweiten Korintherbriefes, Darmstadt 1947.

11 W Schmithals, Wisdom in Corinth, transl J E Steely, Nashville 1971, 260.

$12 \mathrm{~K}$ Hoffmann, Die Toten in Christus. Eine religionsgeschichtliche und exegetische Untersuchung zur paulinischen Eschatologie, Múnster 1978, 267. In dié verband het $\mathrm{R}$ Jewett 'n verdienstelike bydrae gelewer: Paul's Anthropoligical terms: A study of their use in conflict settings, Leiden 1971, veral 274-279.

13 Die Vulgaat vertaal $\varepsilon \dot{\delta} \delta o \kappa \hat{\omega}$ met placeo mihi wat eintlik sou beteken: “... ek hou

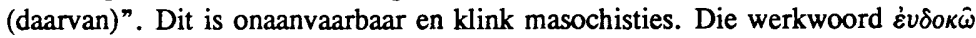


moet eerder vertaal word deur "aanvaar" of om "ja te sê". Die NAV se "bly

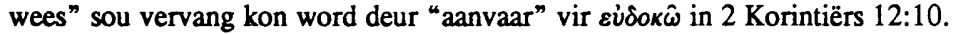

14 Die vertaling "dwing" vir $\sigma \nu \nu \varepsilon ́ \chi \varepsilon \iota$ in 2 Korintiërs 5:14 is nie korrek nie. Die liefde van Christus "hou ons vas" of "beheer ons" of "hou ons orent". $R$ Penna, Paul the Apostle: Jew and Greek alike, (translation P Wahl),

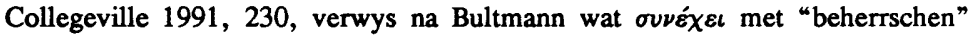
vertaal; Wendland met "hält uns in ihrer Gewalt" en Barrett met "controls our action". Die vertaling "dwing" van die NAV is vreemd. Kyk verder; E Güttgemans, Der leidende Apostel und sein Herr, Göttingen 1966; E Kamlah, Wie beurteilt Paulus sein Leiden? Ein Beitrag zur Untersuchung seiner Denkstruktur, ZNW 54 (1963), 217-232; G G O'Collins, Power made perfect in weakness: 2 Cor 12:9-10, CBQ 33 (1971), 528-537.

15 Die apokaliptiese voorbeelde parallel aan dié gedagte is volop; vergelyk byvoorbeeld Siriese Barug 15:18; 48:50; 51:12; asook 4 Makkabeërs 17:12.

16 Kyk Plato, Phaed 79; Seneca Ep 58:2; Corp Herm 7:1-2.

17 Vergelyk Siriese Barug 52:7; 4 Esra 7:16.

18 Vergelyk in die verband 2 Korintiërs 1:22, asook Efesiërs 1:14 en $\dot{\alpha} \pi \alpha \rho \chi \eta^{\prime}$ in Romeine 8:23.

19 Vergelyk: "kleipotte" (4:7), "in ons liggaam" (4:10 - tweekeer), "in ons sterflike bestaan" (4:11) "ons ook sal opwek" (4:14), "uiterlike" en die "innerlike mens" (4:16), “aardse woning wat maar 'n tent is" (5:1), "woonplek ... nie met hande gemaak nie" (5:1b), "tentwoning" (5:2), "nog in die tentwoning is" (5:4), "aardse liggaam" (5:4), "in die liggaam" (5:6), "ons verblyf in die liggaam" (5:8) "tydens sy aardse lewe" (5:10).

20 Oor dié vraag is al heelwat geskryf en gespekuleer. Vergelyk C Clemen, Religionsgeschichtliche Erklärung des NT, Berlin 1973, 334-335 wat alle metafore parallel terugvoer na die heidense Griekse omgewing. W D Davies interpreteer dit Judaïsties in sy Paul and Rabbinic Judaism, London 1965, en gaan selfs sover om te sê: "The language of Paul can be explained without recourse to Hellenistic sources" (314).

21 Aangehaal deur Penna, Paul the Apostle, 243. Hy verwys ook na J Hering wat meen dat 2 Korintiërs 4:16-18 deur Filo of 'n ander Platoniese outeur geskryf kon gewees het. Vergelyk $\mathrm{H}$ Windisch, Der zweite Korintherbrief, Göttingen 1924, 149.

22 Vergelyk in dié verband ook 1 Korintiërs 2:3-5 en 2 Korintiërs 12:9-10.

23 Tusc I, 22:52; vergelyk Lucretius Rer. Nat. III, 440, 555.

24 Vergelyk in die LXX: Psalm 31(30):12 en Jeremia 22:28.

25 Vergelyk Genesis 2:7; Jesaja 64:8; Romeine 9:20-23.

26 Vergelyk Plato, Rep IX 589; Philo, Det pot ins 22; Epictetus, Diatr III 3L13; Corpus Hermeticum I, 15, XIII en Plotinus, Enn III, 2:15, om die bekendstes te noem.

27 Aldus Plato, Leg XII 959; Rep IV, 430-431. Philo sê van die vov̂ eintlike mens in die mens is, die onsterflike in die sterflike. Kyk sy Quaest Gen I, 79.

28 Kyk sy Phaed, 62.

29 Vergelyk Penna, Paul the Apostle, 247; asook Michaelis, TDNT VII, 381, art oкńvos. 
Senect 23:84.

31 Aldus Sisero, Tusc I, 22:51; Divin I, 25:53. Ook Filo praat van die oiki $\alpha$ as aardse verblyf van die gees: Praem, 120; Det pot ins, 33.

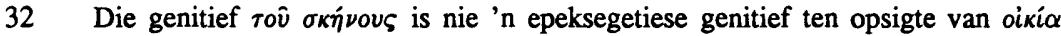
nie maar 'n genitief van spesifikasie.

33 Vergelyk sy Phaed, 67; Apol, 40.

34 Kyk Somn 1, 180-181 Conf, 76-82.

35 Seneka (Ep, 92;13; Ad Marc, 25:1) gebruik ook die metafoor en Plutargus praat daarvan dat die $\psi v \times \dot{\eta}$ wat God liefhet die liggaam soos 'n kledingstuk moet afskud: De Sera, 26.

36 Tipies Judaïsties-apokalipties! In 4 Esra 7:3-25 word 'n vergelyking getref tussen die noute van die huidige lewe en die uitgebreidheid van die toekomstige. Israel se bestemming word dan vergelyk met iemand wat die oop see moet bereik nadat langs ' $n$ smal riviertjie tot daar beweeg is. Daarom moet iemand nie vaskyk teen die huidige noute nie maar konsentreer op die groot oopte wat sal aanbreek.

37 Volgens Judaïstiese apokaliptiese denke word die regverdige wat ly beloon. In die verband het $\mathrm{L}$ Ruppert toonaangewende navorsing gedoen in sy Der leidende Gerechte. Eine motif-geschichtliche Untersuchung zum AT und zwischentestamentlichen Judentum, Würzburg 1972.

38 Vergelyk Seneka, Ep 24, 1920; asook 26:8. Kyk Josefus Bell Jud II, 8:14, 163.

39 Kyk Josefus Bell Jud II, 8:14, 163.

40 Kyk M Collange, Enigmes de la Deuxième Épître aux Corinthiens: II Cor v, 110, Rech SR 44 (1956), 178.

41 'n Deeglike bespreking daarvan vind ons in C C Cavallin, Life after Death I, an enquiry into the Jewish background, Lund 1974, vergelyk 199. Hy sê byvoorbeeld: "... there is obviously no single Jewish doctrine about life after death in the period $(100 \mathrm{BC}-100 \mathrm{AD})$ under consideration; there is rather a great variety and a pluralism of ideas both about the end of world history and about death and about that which follows the death of the individual person".

42 Dit is opvallend dat in Romeine 8:23 die werkwoord "sug" ( $\sigma \tau \varepsilon \nu \alpha \dot{\zeta} \zeta \varepsilon \nu \nu$ ) voorkom in verband met die Gees, net soos in 2 Korintiërs 5:2.

43 Hoe treffend teken W Pfister hierdie aspek in sy Das Leben im Geiste nach Paulus. Der Geist als Anfang und Vollendung des christlichen Lebens, Freiburg 1963. 